\title{
The Effect of Low-Dose Ticagrelor on Platelet Function Profiles in Patients With Stable Coronary Artery Disease in Trinidad: The TWIST Pilot Study
}

\author{
Naveen Seecheran (D) - Brent Boodhai · Aarti Maharaj · \\ Arvinash Ramdeen · Niranjan Debideen • Vishesh Ochalal • \\ Randall Singh · Rajeev Seecheran • Valmiki Seecheran • \\ Sangeeta Persad · Harun Abdullah · Lakshmipathi Peram • \\ Shastri Motilal · Antonio Tello-Montoliu • David Schneider
}

Received: June 17, 2020 / Published online: August 6, 2020

(C) The Author(s) 2020

\section{ABSTRACT}

Introduction: This prospective, pharmacodynamic study aimed to explore the potential applicability of a low-dose ticagrelor regimen in a heterogeneous Trinidadian subpopulation.

Methods: Patients with stable coronary artery disease $(n=25)$ who were actively treated with dual antiplatelet therapy of aspirin $81 \mathrm{mg}$ daily and clopidogrel $75 \mathrm{mg}$ daily were recruited. Platelet function was measured with the VerifyNow $\mathrm{P}^{2} \mathrm{Y}_{12}$ assay (Accriva Diagnostics, San

Digital Features To view digital features for this article go to https://doi.org/10.6084/m9.figshare.12706505.

N. Seecheran $(\bowtie)$

The University of the West Indies, St. Augustine,

Port of Spain, Trinidad and Tobago

e-mail: naveen.seecheran@sta.uwi.edu;

nseecheran@gmail.com

B. Boodhai · A. Maharaj · A. Ramdeen ·

N. Debideen · V. Ochalal · R. Singh · R. Seecheran ·

V. Seecheran · S. Persad · H. Abdullah · L. Peram .

S. Motilal

North Central Regional Health Authority, Champs

Fleurs, Mount Hope, Trinidad and Tobago

A. Tello-Montoliu

Universidad de Murcia, Murcia, Spain

D. Schneider

Cardiovascular Research Institute of Vermont,

Colchester, Vermont, USA
Diego, CA, USA) and assessed before initiation of and after 14 days of treatment with a lowdose ticagrelor $45 \mathrm{mg}$ twice daily maintenance dose regimen. Results were compared with a paired $t$ test.

Results: The mean $\mathrm{P}_{2} \mathrm{Y}_{12}$ reaction units (PRU) score on ticagrelor was significantly less compared to that of clopidogrel $(50.4,95 \%$ confidence interval (CI) 29-73.9; vs. 149.6, 95\% CI $129.4-169.9$; $p$ value $<0.001)$. Of the patients, $4 \%$ experienced Medical Research Council class 1 dyspnea, and Bleeding Academic Research Consortium class 1 bleeding on the ticagrelor regimen (one patient each).

Conclusions: Significantly attenuated platelet reactivity was seen on the low ticagrelor maintenance dose as compared to clopidogrel. This dedicated pharmacodynamic study could be applicable and informative for Trinidadian stable coronary artery disease patients. Further studies are required to confirm these exploratory findings.(Funded by the University of the West Indies, St. Augustine).

Trial Registration: ClinicalTrials.gov number NCT04206176.

Keywords: Clopidogrel; High on-treatment platelet reactivity; Ticagrelor; VerifyNow 


\section{Key Summary Points}

Why carry out this study?

Clopidogrel has been a mainstay of dual antiplatelet therapy (DAPT) for well over 20 years, whereas ticagrelor has recently emerged as a potent P2Y12 antiplatelet agent for the better part of the last decade. Low-dose ticagrelor can be considered a potential therapeutic option for some Asian patients.

The Trinidadian population is a melting pot of diverse ethnicities; some of which are known to possess characteristic atherothrombotic and bleeding risk profiles, such as the "East Asian paradox" with respect to platelet reactivity, however clinical efficacy and safety data with low-dose ticagrelor are lacking in this setting and remain virtually unknown in these racial subgroups.

What was learned from the study?

Low-dose ticagrelor significantly attenuated platelet reactivity as compared to standard-dose clopidogrel in this heterogeneous Trinidadian subpopulation.

A low-dose ticagrelor regimen could be considered in a Trinidadian setting to mitigate both atherothrombotic and bleeding risk, a population previously described to have high on-treatment platelet reactivity (HPR). Further research is required to confirm and clinically validate these exploratory findings.

\section{INTRODUCTION}

Clopidogrel has been an integral component of dual antiplatelet therapy (DAPT) for cardiovascular disease (CVD) for well over two decades, as demonstrated in several key landmark trials
[1-3]. However, the pharmacodynamic (PD) effects of clopidogrel are heterogeneous and impacted by a multitude of genetic, drug interaction, and clinical factors, leading to a broad interindividual response $[4,5]$. A recent study performed by Seecheran et al. in Trinidad demonstrated the estimated prevalence of high on-treatment platelet reactivity (HPR) to be considerably higher at $50 \%$, even more so in the South Asian subpopulation at $60 \%$ [6]. Within the last decade, novel, more potent $\mathrm{P}_{2} \mathrm{Y}_{12}$ inhibitors, such as ticagrelor, have gained traction as a preferred strategy to mitigate HPR [7]. Ticagrelor is an oral $\mathrm{P}_{2} \mathrm{Y}_{12}$ receptor inhibitor that provides a more substantial and consistent antiplatelet effect compared to clopidogrel, notably with respect to potency, onset, and offset of action [7]. The PLATO trial (Study of Platelet Inhibition and Patient Outcomes) evaluated ticagrelor and was associated with a net clinical benefit from a significant reduction in cardiovascular events at the expense of increased bleeding events, in comparison with clopidogrel in patients with acute coronary syndromes (ACS) [8].

In the South Asian, Trinidadian, and Caribbean populations, the literature is not replete with evidence comparing low versus standard doses of ticagrelor to evaluate clinical effectiveness and safety. A recent East Asian systematic review suggested that low-dose ticagrelor revealed an antiplatelet efficacy similar to that of standard-dose ticagrelor, which was faster and more potent than clopidogrel, however, required further evaluation in a largescale randomized clinical trial [9]. These findings raised the question as to whether the current recommended dose of ticagrelor is suitable for the Trinidadian population, a population often described as multiethnic and cosmopolitan, comprising an admixture of South Asian, Caribbean Black, East Asian, Arabic, and Caucasian ancestries [6, 10]. Therefore, we conducted this exploratory pilot study to assess the antiplatelet PD effect of low-dose ticagrelor in a Trinidadian subpopulation with stable coronary artery disease (CAD). 


\section{METHODS}

\section{Study Design and Patient Population}

The study complied with the Declaration of Helsinki, International Conference on Harmonization, Good Clinical Practice, and was approved by the Campus Research Ethics Committee of the University of the West Indies, St. Augustine, Trinidad [11, 12]. All participants provided written informed consent to participate in a prospective, open-label study aimed to assess the effect of low-dose ticagrelor $45 \mathrm{mg}$ twice daily as compared to clopidogrel $75 \mathrm{mg}$ once daily. Patients were screened and enrolled between November 2019 and December 2019 at the cardiology outpatient clinic at our institution (Eric Williams Medical Sciences Complex, Trinidad and Tobago). They were considered eligible for the study if they were above 18 years of age and awaiting elective percutaneous coronary intervention (PCI) or coronary artery bypass grafting (CABG) on dual antiplatelet therapy (DAPT) for at least 4 weeks with aspirin $81 \mathrm{mg}$ per day maintenance dose and clopidogrel $75 \mathrm{mg}$ per day maintenance dose. Exclusion criteria for this study included an acute coronary syndrome within 6 months, active bleeding, prior cerebrovascular event, clinical instability after an index event, use of an oral anticoagulation agent (warfarin derivative or other anticoagulant therapy (such as dabigatran, rivaroxaban, apixaban, edoxaban), platelet count $<100 \times 10^{6} / \mu \mathrm{l}$, hemoglobin $<10 \mathrm{~g} / \mathrm{dl}$, serum creatinine $>2.5 \mathrm{mg} / \mathrm{dl}$, patients on concurrent CYP 2C19 inhibitors, and CYP 3A4 inducers. They were followed up for 28 days post-procedure after completing the study to assess whether they experienced any adverse events.

\section{Blood Sampling and VerifyNow $\mathrm{P}^{2} \mathrm{Y}_{12}$ Testing}

Clopidogrel was held on the morning of their fasting scheduled visit (8:00-9:00 am) (18-24 h before baseline blood sampling), which ensured the determination of trough levels of platelet reactivity. Blood samples were obtained at rest by antecubital puncture using a 21-gauge needle and placed into Vacuette (Greiner Bio-One North America, Monroe, NC, USA) blood collecting tubes containing 3.8\% trisodium citrate after discarding the first $5 \mathrm{ml}$ of blood to avoid artifactual platelet activation. Samples were processed by laboratory personnel blinded to ongoing study data. Platelet function assays included the VerifyNow P2Y 12 (VN-P2 $\mathrm{Y}_{12}$ ) assay (Accriva Diagnostics, San Diego, CA, USA). The assays were performed according to standard protocols, as previously described [13, 14]. The VN-P2 $\mathrm{Y}_{12}$ assay reports the results as $\mathrm{P}_{2} \mathrm{Y}_{12}$ reaction units (PRU). A PRU $>208$ was considered HPR according to the last consensus [2]. The enrolled patients were then treated with ticagrelor $45 \mathrm{mg}$ twice daily for 2 weeks with pill accountability by the clinical research associate. The ticagrelor $90 \mathrm{mg}$ tablet was attempted to be evenly divided into halves (each containing $45 \mathrm{mg}$ of ticagrelor) using a standard pill-cutter, as suggested by Li et al. [15]. Ticagrelor $60 \mathrm{mg}$ was not available in Trinidad. After 2 weeks of low-dose ticagrelor regimen, platelet reactivity was assessed a second time with the VN-P2Y 12 assay using the aforementioned methodology (see Fig. 1).

\section{Patient Interview and Case Report Form}

The patients' demographic data were recorded on a case report form (CRF) and included the patient's medical, procedural history, and any cardiovascular medications.

\section{Statistical Analysis}

The sample size was calculated as 25 patients based on a paired proportion sample, an alpha ( $\alpha$ ) value of 0.05 , power of $80 \%$, estimated baseline prevalence of $30 \%$ of PRU $>208$, and absolute delta of $20 \%$ (expected prevalence of $30 \%$ of PRU $>208$ ). Continuous variables were expressed as mean \pm standard deviation and categorical variables as frequencies and percentages. Paired $t$ tests were used for comparisons of mean differences in PRU scores and McNemar's test for comparison of paired proportions. No adjustments for multiple 


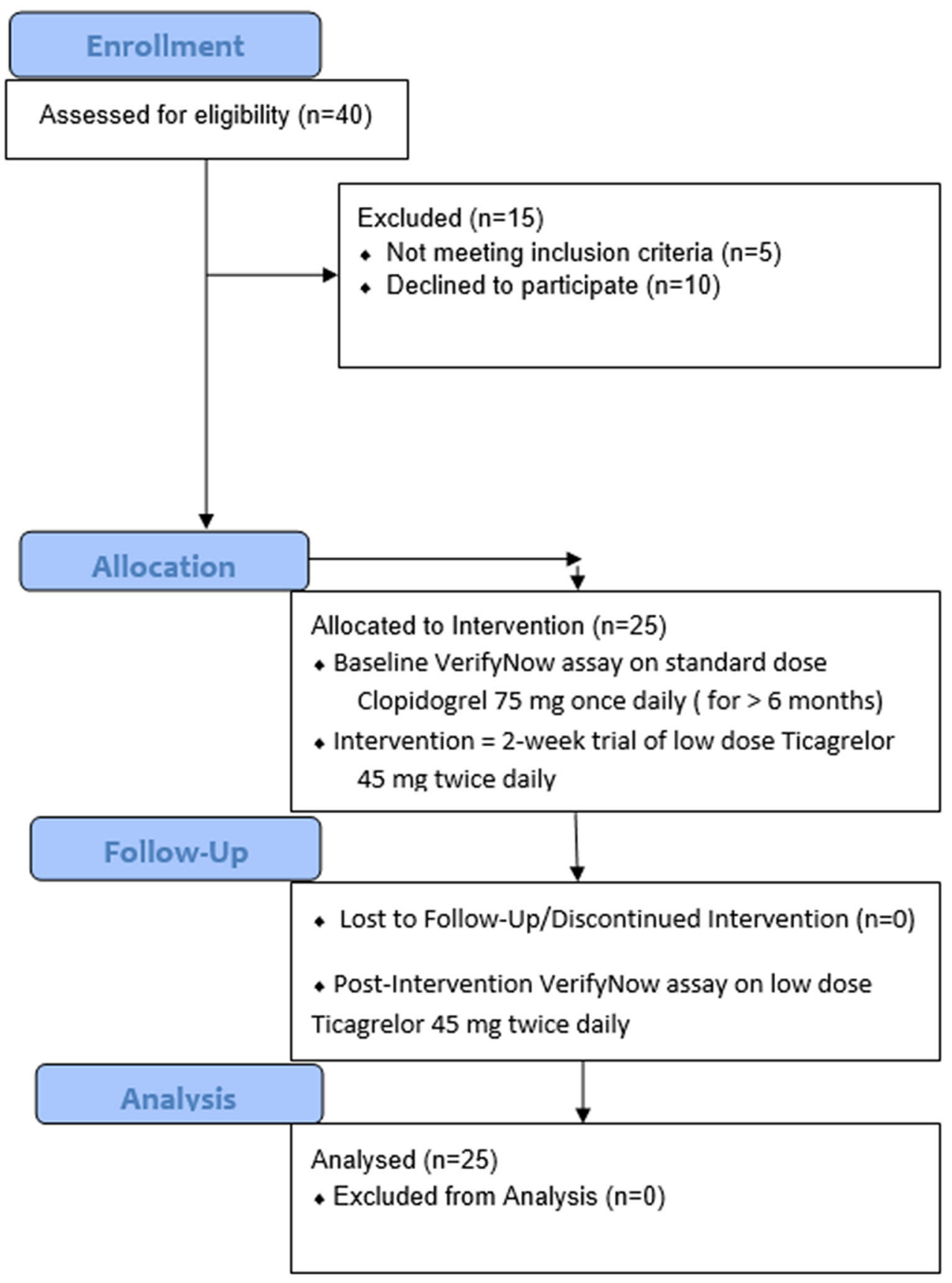

Fig. 1 Methodology outline

comparisons were made. Missing data were not imputed (none). A two-tailed $p$ value of 0.05 was considered to indicate a statistically significant difference for all the analyses performed. Statistical analysis was performed using SPSS version 24.0 software (IBM SPSS Statistics, New York, NY, USA).

\section{RESULTS}

A total of 25 individuals with stable CAD on DAPT with aspirin and clopidogrel were enrolled in the study. Table 1 shows the demographics of the study participants. The mean 
Table 1 Patient population

\begin{tabular}{|c|c|}
\hline Characteristics & Frequency (\%) \\
\hline Age & $\begin{array}{l}63.3 \text { years (mean) } \\
\text { (range, } 48-79 \text { years) }\end{array}$ \\
\hline \multicolumn{2}{|l|}{ Gender } \\
\hline Female & $14(56)$ \\
\hline Male & $11(44)$ \\
\hline \multicolumn{2}{|l|}{ Ethnicity } \\
\hline South Asian & $16(64)$ \\
\hline Caribbean Black & $5(20)$ \\
\hline Interracial & $4(16)$ \\
\hline Body mass index & $\begin{array}{l}27.3 \mathrm{~kg} / \mathrm{m}^{2} \text { (mean) } \\
(\text { range, } 21.4-36.1 \mathrm{~kg} / \\
\left.\mathrm{m}^{2}\right)\end{array}$ \\
\hline \multicolumn{2}{|l|}{ Comorbidities } \\
\hline Prior myocardial infarction & $8(32)$ \\
\hline Diabetes mellitus & $15(60)$ \\
\hline Hypertension & $21(84)$ \\
\hline Dyslipidemia & $18(72)$ \\
\hline Chronic kidney disease & $2(8)$ \\
\hline Cerebrovascular events & $11(44)$ \\
\hline $\begin{array}{l}\text { Chronic obstructive pulmonary } \\
\text { disease }\end{array}$ & $1(4)$ \\
\hline Peripheral artery disease & $0(0)$ \\
\hline \multicolumn{2}{|l|}{ Cardiovascular medications } \\
\hline Aspirin & $25(100)$ \\
\hline Clopidogrel & $25(100)$ \\
\hline Angiotensin-converting enzyme & $18(72)$ \\
\hline $\begin{array}{l}\text { Inhibitor/angiotensin receptor } \\
\text { blocker }\end{array}$ & $23(92)$ \\
\hline \multicolumn{2}{|l|}{ Beta-blocker } \\
\hline Statin & $24(96)$ \\
\hline Calcium channel blocker & $9(36)$ \\
\hline Nitrates & $12(48)$ \\
\hline
\end{tabular}

Table 1 continued

\begin{tabular}{ll}
\hline Characteristics & Frequency (\%) \\
\hline $\begin{array}{l}\text { Mineralocorticoid receptor } \\
\text { antagonist }\end{array}$ & $5(20)$ \\
Ivabradine & $0(0)$ \\
Sacubitril & $0(0)$ \\
Trimetazidine & $17(68)$ \\
Diabetic medications & \\
Insulins & $5(20)$ \\
Oral hypoglycemics & $1(4)$ \\
Cardiovascular procedures & \\
Percutaneous coronary & $5(20)$ \\
intervention & \\
Coronary artery bypass grafting & $2(8)$ \\
\hline
\end{tabular}

age was 63.3 years. Of the patients, just over half were females, with the same percentage being South Asian in ethnicity and the remainder, Caribbean Black, Caucasian, and interracial. The mean body mass index (BMI) was $27.3 \mathrm{~kg} / \mathrm{m}^{2}$. The prevalence of prior myocardial infarction was almost one-third; diabetes was $60 \%$, with hypertension slightly greater than $80 \%$, dyslipidemia roughly $70 \%$, and cerebrovascular events, more than $40 \%$. Chronic kidney, lung, and peripheral artery disease each accounted for less than 10\% comorbidity. There was also a prevalence of at least $70 \%$ use of angiotensin-converting enzyme (ACE) inhibitors, and over 90\% for both beta-blockers and high-intensity statins. Onefifth of patients had previously been treated with percutaneous coronary intervention (PCI) and less than $10 \%$ with coronary artery bypass grafting (CABG).

The mean PRU on ticagrelor was significantly less than that of clopidogrel $(50.4,95 \%$ confidence interval (CI) 29-73.9; vs. 149.6, 95\% CI 129.4-169.9; $p$ value $<0.001$ ) (see Table 2 and Fig. 2). One patient experienced Bleeding Academic Research Consortium (BARC) class 1 bleeding during ticagrelor therapy, described as non-actionable, mild ecchymosis on her left 
Table 2 Comparison of standard-dose clopidogrel $75 \mathrm{mg}$ once daily versus low-dose ticagrelor $45 \mathrm{mg}$ twice daily on platelet reaction units (PRU)

\begin{tabular}{lllll}
\hline & $\begin{array}{l}\text { Mean platelet reaction units } \\
(\text { PRU) }\end{array}$ & $\begin{array}{l}\text { Lower 95\% confidence } \\
\text { interval }(\mathbf{C I})\end{array}$ & $\begin{array}{l}\text { Upper 95\% confidence } \\
\text { interval }(\mathbf{C I})\end{array}$ & $\boldsymbol{p}$ value \\
\hline Clopidogrel & 149.64 & 129.41 & 169.87 & $<0.001$ \\
Ticagrelor & 50.44 & 29.00 & 73.88 & \\
\hline
\end{tabular}

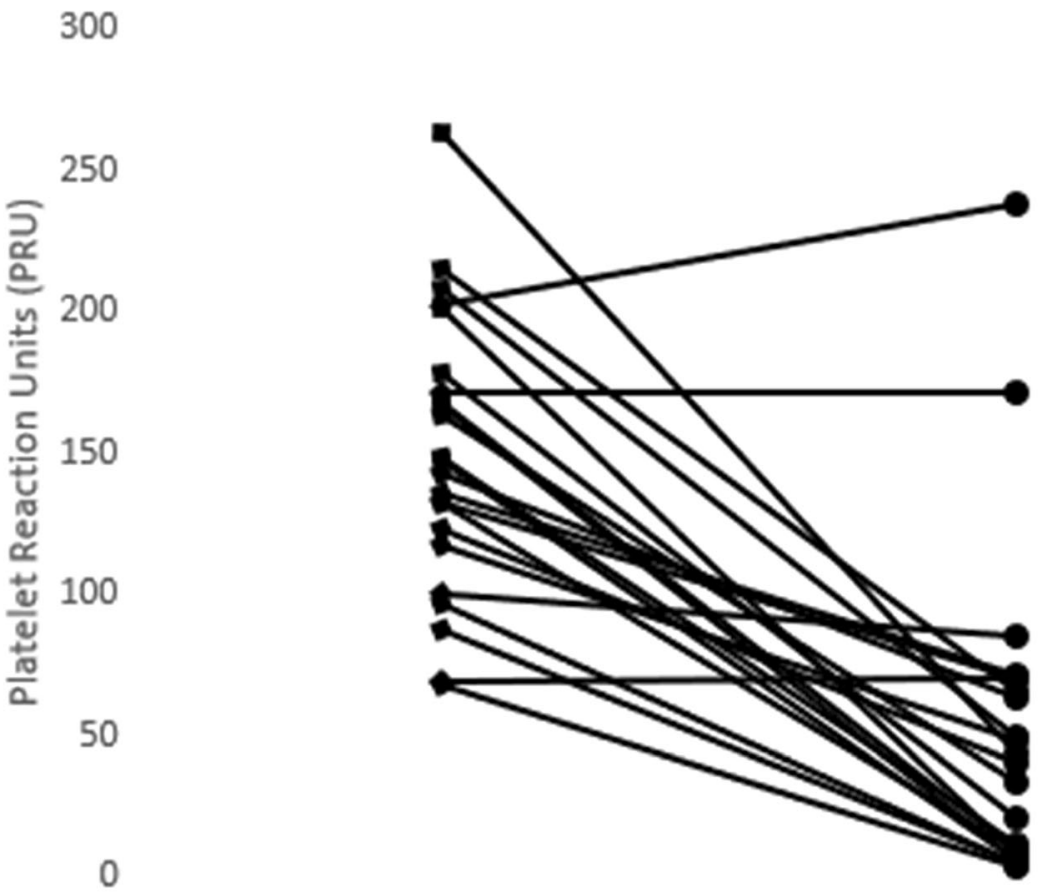

- Standard Dose Clopidogrel (Baseline)

- Low dose Ticagrelor after 2 weeks ( $45 \mathrm{mg}$ bd)

Fig. 2 Comparison of patients' $\mathrm{P}^{2} \mathrm{Y}_{12}$ reaction units (PRU) on standard-dose clopidogrel $75 \mathrm{mg}$ once daily versus low-dose ticagrelor $45 \mathrm{mg}$ twice daily

upper extremity, while another experienced Medical Research Council (MRC) class 1 dyspnea for which they both continued the ticagrelor regimen without interruption.

\section{DISCUSSION}

This dedicated study explored the PD effects of a low-dose ticagrelor regimen in Trinidadian patients with stable CAD. Ticagrelor is an oral $\mathrm{P}^{2} \mathrm{Y}_{12}$ receptor inhibitor that is biologically active (not a prodrug) and binds reversibly to the $\mathrm{P}_{2} \mathrm{Y}_{12}$ receptor. Ticagrelor has been shown to provide a more powerful and consistent antiplatelet effect compared to clopidogrel. Clopidogrel is a prodrug that requires two-step metabolism by CYP enzymes to become an active metabolite, resulting in substantial variability in inter-individual response [16]. 
Establishing optimal antiplatelet efficacy while minimizing adverse events is pivotal to the tenet of $\mathrm{P}_{2} \mathrm{Y}_{12}$ inhibition. Several mechanistic studies assess the concept of "less is more" with respect to the delicate balance of ischemic protection and bleeding. In the PEGASUS-TIMI 54 (Patients with Prior Heart Attack Using Ticagrelor Compared to Placebo on a Background of Aspirin-Thrombolysis In Myocardial Infarction 54) trial, both ticagrelor doses (90 mg and $60 \mathrm{mg}$ ) reduced ischemic events, with the 60-mg dose demonstrating a more attractive benefit-to-risk profile with further clinical consideration of extending DAPT in patients with high ischemic and low bleeding risks [17]. The ALTIC (A Randomized, Pharmacodynamic Comparison of Low-Dose Ticagrelor to Clopidogrel) compared ticagrelor $60 \mathrm{mg}$ twice daily with clopidogrel $75 \mathrm{mg}$ in patients with at least one high-risk feature (age $>65$ years, diabetes mellitus, prior myocardial infarction, multivessel disease, or renal dysfunction) and revealed that ticagrelor $60 \mathrm{mg}$ twice daily provides greater platelet inhibition than clopidogrel $75 \mathrm{mg}[18,19]$.

However, the vast majority of mechanistic platelet function studies evaluating the PD effects of permutations of various antiplatelet strategies are based upon predominantly Caucasian populations. Trinidad is considered ethnically diverse, with the population comprising approximately one-half South Asian, one-third Caribbean Black, and the remaining one-third, mostly East Asian, Caucasian, Arabic, and interracial [20]. South Asians have higher proportional mortality rates from CAD compared with other Asian groups [21]. In a recent pilot study, the estimated prevalence of HPR was considerably higher at 50\%, with HPR being more prevalent in the South Asian ethnicity [6]. To our knowledge, these novel regimens and doses remain untested in these ethnic minority subpopulations, such as Trinidad, and to a broader region, the Caribbean.

Several studies explored low-dose ticagrelor regimens in East Asian ethnicity [9]. East Asians are susceptible to increased bleeding events when compared to other races after the administration of antiplatelet agents [22-24]. A recent systematic review, including two clinical studies, compared and evaluated the niche of a lower dose versus standard dose of ticagrelor in East Asians, which revealed similar efficacy [9]. Generally, there was a higher incidence of adverse events observed in the standard ticagrelor dose; however, no formal conclusions could be drawn, as the studies were hindered by limited patient enrollment and outcomes, warranting larger-scale studies [9]. In the PEGASUSTIMI 54 study, there was a caveat that an Asian subgroup analysis should be interpreted with caution, as it was likely underpowered to detect significant geographical differences [17]. The PHILO study assessed outcomes in Japanese, Korean, and Taiwanese ACS patients undergoing PCI and revealed there were no significant differences between clopidogrel and ticagrelor in clinical efficacy and major bleeding; however, a composite of major and minor bleeding occurred at a higher rate in the ticagrelor allocation, calling into question the clinical equipoise and pragmatism of this potent $\mathrm{P}_{2} \mathrm{Y}_{12}$ inhibitor in East Asians [22]. As a result, there was a suggestion put forward to evaluate lower doses of ticagrelor in this population [23]. Of note, in Japan, other widely used oral $\mathrm{P}_{2} \mathrm{Y}_{12}$ receptor antagonists such as clopidogrel and prasugrel have been approved at lower doses than the doses approved worldwide based on pharmacokinetic (PK) and PD studies of these agents [24]. Overall, it has been suggested that East Asians appear to possess a contrasting therapeutic window for platelet reactivity, as they tend to display HPR after antiplatelet agents with respective lower thrombotic events, dubbed the "East Asian paradox" [25, 26]. The rationale for such differences is not fully elucidated; however, attributed to genetic, cellular, plasmatic, and inflammatory factors [27]. Additionally, there has been the observance of increased risk of bleeding, including intracranial hemorrhage in East Asians, due to anthropometric differences [28, 29]. To our knowledge, these phenomena have not yet been described in the South Asian ethnicity, amongst others, and within the scope of the Caribbean.

It appeared that at low doses of ticagrelor $45 \mathrm{mg}$ twice daily, potent platelet inhibition occurred, which was significantly more than 
clopidogrel. By illustrating that this low-dose regimen provided a more potent and consistent antiplatelet effect, this mechanistic study can be potentially clinically relevant. In fact, because of the tolerability and safety profile in this population, larger studies are warranted to ascertain clinical outcomes on this regimen.

\section{Study Limitations}

Although the study was relatively small $(n=25)$, it was adequately powered for PD outcomes. There was a relatively high prevalence history of prior myocardial infarction, diabetes mellitus, and cerebrovascular events, approximately $32 \%, 60 \%$, and $44 \%$, alluding to a stable but albeit high-risk population [30]. Diabetes is implicated in accentuating platelet reactivity via a complex thrombotic milieu [5]. The study also had a relatively higher proportion of women (56\%) as compared to prior studies performed by this group in a similar setting $[6,10]$. Thus, any emerging recommendations cannot be extrapolated to other populations, such as patients with ACS. The patient population constituted almost two-thirds of South Asians, whose ethnicity has also been linked with HPR [6]. These issues may suggest an inherent selection bias. Additionally, it is possible for a temporal effect to potentially confound the study results. It would be ideal to perform other platelet function tests such as light transmittance aggregometry or multiple electrode aggregometry; however, these modalities are not currently available in Trinidad. Another potential limitation is that the $90-\mathrm{mg}$ ticagrelor pill may not have been evenly divided. The study was not powered to assess clinical outcomes; therefore, no safety or efficacy conclusion on low-dose ticagrelor in stable CAD can be drawn; and, the rates of adverse events, although minimal, cannot be definitively concluded from this study from the relatively small number of patients enrolled.

\section{CONCLUSIONS}

This mechanistic study can be clinically pertinent because of improved efficacy, safety, and tolerability profile. Low-dose ticagrelor achieved a greater antiplatelet effect than clopidogrel and led to significantly lower platelet reactivity than clopidogrel, with $4 \%$ of patients experiencing high on-treatment platelet reactivity.

\section{ACKNOWLEDGEMENTS}

Funding. Campus Research and Publication Fund (CRP.4MAR16.38(3)) from the University of the West Indies, St. Augustine for TTD 22,125 . These funds were utilized for purchasing the VerifyNow P2Y12 (VN-P2Y12) assay kits (Accriva Diagnostics, San Diego, CA, USA). The journal's rapid service fee was funded by the authors.

Authorship. All named authors meet the International Committee of Medical Journal Editors (ICMJE) criteria for authorship for this article, take responsibility for the integrity of the work as a whole, and have given their approval for this version to be published.

Authorship Contributions. All authors contributed equally in writing the manuscript. All authors read and approved the final manuscript.

Disclosures. Naveen Seecheran, Brent Boodhai, Aarti Maharaj, Arvinash Ramdeen, Niranjan Debideen, Vishesh Ochalal, Randall Singh, Rajeev Seecheran, Valmiki Seecheran, Sangeeta Persad, Harun Abdullah, Lakshmipathi Peram, Shastri Motilal, Antonio Tello-Montoliu, and David Schneider have nothing to disclose.

Compliance with Ethics Guidelines. The study complied with the Declaration of Helsinki, International Conference on Harmonization, Good Clinical Practice, and was approved by the Campus Research Ethics Committee of the University of the West Indies, St. Augustine, Trinidad. All participants provided written informed consent. 
Data Availability. All available data can be obtained by contacting the corresponding author. TWIST ClinicalTrials.gov number NCT04206176. All materials, data, code, and associated protocols will be made promptly available to the editor and readers upon request. If requested, there will not be any restrictions on the availability of materials.

Open Access. This article is licensed under a Creative Commons Attribution-NonCommercial 4.0 International License, which permits any non-commercial use, sharing, adaptation, distribution and reproduction in any medium or format, as long as you give appropriate credit to the original author(s) and the source, provide a link to the Creative Commons licence, and indicate if changes were made. The images or other third party material in this article are included in the article's Creative Commons licence, unless indicated otherwise in a credit line to the material. If material is not included in the article's Creative Commons licence and your intended use is not permitted by statutory regulation or exceeds the permitted use, you will need to obtain permission directly from the copyright holder. To view a copy of this licence, visit http://creativecommons.org/licenses/by$\mathrm{nc} / 4.0 /$.

\section{REFERENCES}

1. Levine GN, Bates ER, Bittl JA, Brindis RG, Fihn SD, Fleisher LA, et al. ACC/AHA Guideline Focused Update on Duration of Dual Antiplatelet Therapy in Patients With Coronary Artery Disease: A Report of the American College of Cardiology/American Heart Association Task Force on Clinical Practice Guidelines: An Update of the 2011 ACCF/AHA/ SCAI Guideline for Percutaneous Coronary Intervention, 2011 ACCF/AHA Guideline for Coronary Artery Bypass Graft Surgery, 2012 ACC/AHA/ACP/ AATS/PCNA/SCAI/STS Guideline for the Diagnosis and Management of Patients With Stable Ischemic Heart Disease, 2013 ACCF/AHA Guideline for the Management of ST-Elevation Myocardial Infarction, 2014 AHA/ACC Guideline for the Management of Patients With Non-ST-Elevation Acute Coronary Syndromes, and 2014 ACC/AHA Guideline on Perioperative Cardiovascular Evaluation and Management of Patients Undergoing Noncardiac
Surgery [Internet]. Circulation. 2016. https://doi. org/10.1161/cir.0000000000000404.

2. Tantry US, Bonello L, Aradi D, Price MJ, Jeong Y-H, Angiolillo DJ, et al. Consensus and update on the definition of on-treatment platelet reactivity to adenosine diphosphate associated with ischemia and bleeding. J Am Coll Cardiol [Internet]. 2013;62(24):2261-73. https://doi.org/10.1016/j. jacc.2013.07.101.

3. Matetzky S, Shenkman B, Guetta V. Clopidogrel resistance is associated with increased risk of recurrent atherothrombotic events in patients with acute myocardial infarction [Internet]. ACC Curr J Rev. 2004;13(9):9. https://doi.org/10.1016/j. accreview.2004.08.004.

4. Franchi F, Angiolillo DJ. Novel antiplatelet agents in acute coronary syndrome [Internet]. Nat Rev Cardiol. 2015;12:30-47. https://doi.org/10.1038/ nrcardio.2014.156.

5. Schneider DJ. Factors contributing to increased platelet reactivity in people with diabetes. Diabetes Care [Internet]. 2009;32(4):525-7. https://doi.org/ $10.2337 / \mathrm{dc} 08-1865$.

6. Seecheran NA, Maharaj A, Boodhai B, Seecheran R, Seecheran V, Persad S, et al. Prevalence of clOpidogrel "resIstaNce" in a selected population of patients undergoing elective percutaneous coronary intervention at a tertiary cardiovascular centre in Trinidad: the POINT pilot study. Open Heart [Internet]. 2019;6(1):e000841. https://doi.org/10. 1136/openhrt-2018-000841.

7. Rollini F, Franchi F, Angiolillo DJ. Switching P2Y12receptor inhibitors in patients with coronary artery disease [Internet]. Nat Rev Cardiol. 2016;13:11-27. https://doi.org/10.1038/nrcardio.2015.113.

8. Wallentin L, Becker RC, Budaj A, Cannon CP, Emanuelsson $\mathrm{H}$, Held C, et al. Ticagrelor versus clopidogrel in patients with acute coronary syndromes [Internet]. N Engl J Med. 2009;361:1045-57. https://doi.org/10.1056/nejmoa0904327.

9. Lee YJ, Kim H, Choi J, Lee BH, Lee S-Y. Evaluation of pharmacokinetic, pharmacodynamic, efficacy, and safety data of low-dose ticagrelor versus standard dose in East Asians: a systematic review. Ther Clin Risk Manag [Internet]. 2018;14:83-93. https://doi. org/10.2147/TCRM.S152276.

10. Seecheran N, Seebalack V, Seecheran R, Maharaj A, Boodhai B, Seecheran V, et al. TRimetazidine as an Agent to affeCt clopidogrEl Response: THE TRACER Study. Cardiol Ther [Internet]. 2019. https://doi. org/10.1007/s40119-019-0139-0. 
11. Christie B. Doctors revise declaration of Helsinki. BMJ. 2000;321(7266):913. https://doi.org/10.1136/ bmj.321.7266.913.

12. International Conference on Harmonisation of Technical Requirements for Registration of Pharmaceuticals for Human Use (ICH). In: Wiley Encyclopedia of Clinical Trials [Internet]. 2008. https:// doi.org/10.1002/9780471462422.eoct457.

13. Angiolillo DJ, Badimon JJ, Saucedo JF, Frelinger AL, Michelson AD, Jakubowski JA, et al. A pharmacodynamic comparison of prasugrel vs high-dose clopidogrel in patients with type 2 diabetes mellitus and coronary artery disease: results of the Optimizing anti-Platelet Therapy In diabetes MellitUS (OPTIMUS)-3 Trial. Eur Heart J [Internet]. 2011;32(7):838-46. https://doi.org/10.1093/ eurheartj/ehq494.

14. Angiolillo DJ, Saucedo JF, Deraad R, Frelinger AL, Gurbel PA, Costigan TM, et al. Increased platelet inhibition after switching from maintenance clopidogrel to prasugrel in patients with acute coronary syndromes: results of the SWAP (SWitching Anti Platelet) study. J Am Coll Cardiol [Internet]. 2010;56(13):1017-23. https://doi.org/10. 1016/j.jacc.2010.02.072.

15. Li P, Gu Y, Yang Y, Chen L, Liu J, Gao L, et al. Lowdose ticagrelor yields an antiplatelet efficacy similar to that of standard-dose ticagrelor in healthy subjects: an open-label randomized controlled trial. Sci Rep [Internet]. 2016;6:31838. https://doi.org/10. 1038/srep31838.

16. Ahmad T, Voora D, Becker RC. The pharmacogenetics of antiplatelet agents: towards personalized therapy? [Internet]. Nat Rev Cardiol. 2011;8: 560-71. https://doi.org/10.1038/nrcardio.2011. 111.

17. Storey RF, Angiolillo DJ, Bonaca MP, Thomas MR, Judge HM, Rollini F, et al. Platelet inhibition with ticagrelor $60 \mathrm{mg}$ versus $90 \mathrm{mg}$ twice daily in the PEGASUS-TIMI 54 Trial [Internet]. J Am Coll Cardiol. 2016;67:1145-54. https://doi.org/10.1016/j. jacc.2015.12.062.

18. Despotopoulos S, Xanthopoulou I, Davlouros P, Alexopoulos D. TCT-584 A randomized, pharmacodynamic comparison of low dose ticagrelor to clopidogrel in patients with prior myocardial infarction: The ALTIC study [Internet]. J Am Coll Cardiol. 2017;70:B241-2. https://doi.org/10.1016/j. jacc.2017.09.768.

19. Park D-W, Lee PH, Jang S, Lim H-S, Kang D-Y, Lee $\mathrm{CH}$, et al. Effect of low-dose versus standard-dose ticagrelor and clopidogrel on platelet inhibition in acute coronary syndromes. J Am Coll Cardiol
[Internet]. 2018;71(14):1594-5. https://doi.org/10. 1016/j.jacc.2018.02.010.

20. Seecheran N, Baldeo S, Balbosa K, Baksh S, Bethelmy S, Balkaran S, et al. Epidemiologic insight into Trinidad's awareness and prevention of heart disease. The EPITAPH study-a Trinidadian cardiovascular health literacy survey. Int J Community Med Public Health. 2017;4:903. https://doi.org/10. 18203/2394-6040.ijcmph20171305.

21. Volgman AS, Palaniappan LS, Aggarwal NT, Gupta M, Khandelwal A, Krishnan AV, et al. Atherosclerotic cardiovascular disease in South Asians in the United States: epidemiology, risk factors, and treatments: a scientific statement from the American Heart Association. Circulation [Internet]. 2018;138(1):e1-34. https://doi.org/10.1161/CIR. 0000000000000580 .

22. Goto S, Huang C-H, Park S-J, Emanuelsson H, Kimura T. Ticagrelor vs. clopidogrel in Japanese, Korean and Taiwanese patients with acute coronary syndrome-randomized, double-blind, phase III PHILO study. Circ J [Internet]. 2015;79(11): 2452-60. https://doi.org/10.1253/circj.CJ-15-0112.

23. Serebruany VL, Tomek A, Pya Y, Bekbossynova M, Kim MH. Inferiority of ticagrelor in the PHILO trial: Play of chance in East Asians or nightmare confirmation of PLATO-USA? Int J Cardiol [Internet]. 2016;215:372-6. https://doi.org/10.1016/j.ijcard. 2016.04.125.

24. Saito S, Isshiki T, Kimura T, Ogawa H, Yokoi H, Nanto $S$, et al. Efficacy and safety of adjusted-dose prasugrel compared with clopidogrel in Japanese patients with acute coronary syndrome: the PRASFIT-ACS study. Circ J [Internet]. 2014;78(7): 1684-92. https://doi.org/10.1253/circj.cj-13-1482.

25. Huo Y, Jeong Y-H, Gong Y, Wang D, He B, Chen J, et al. 2018 update of expert consensus statement on antiplatelet therapy in East Asian patients with ACS or undergoing PCI [Internet]. Sci Bull. 2019;64: 166-79. https://doi.org/10.1016/j.scib.2018.12.020.

26. Jeong Y-H. East Asian paradox": challenge for the current antiplatelet strategy of "one-guideline-fitsall races" in acute coronary syndrome. Curr Cardiol Rep [Internet]. 2014;16(5):485. https://doi.org/10. 1007/s11886-014-0485-4.

27. Lutsey PL, Cushman M, Steffen LM, Green D, Barr RG, Herrington D, et al. Plasma hemostatic factors and endothelial markers in four racial/ethnic groups: the MESA study [Internet]. J Thromb Haemost. 2006;4:2629-35. https://doi.org/10.1111/j. 1538-7836.2006.02237.x.

28. Teng R, Butler K. Pharmacokinetics, pharmacodynamics, and tolerability of single and multiple 
doses of ticagrelor in Japanese and Caucasian volunteers [Internet]. Int J Clin Pharmacol Ther. 2014;52:478-91. https://doi.org/10.5414/ cp202017.

29. Shen AY-J, Yao JF, Brar SS, Jorgensen MB, Chen W. Racial/ethnic differences in the risk of intracranial hemorrhage among patients with atrial fibrillation
[Internet]. J Am Coll Cardiol. 2007;50:309-15. https://doi.org/10.1016/j.jacc.2007.01.098.

30. Seecheran N, Nandlal N, Nankissoon S, Nancoo C, Nelson C, Nkemakolam A, et al. A Trinidadian cardiovascular medication adherence survey: the ADHERE TNT study [Internet]. Int J Community Med Public Health. 2017;4:3601. https://doi.org/10. 18203/2394-6040.ijcmph20174218. 